\title{
Paideusis
}

\section{Responsibility for Beliefs and Emotions}

\section{Miriam McCormick and Michael Schleifer}

Volume 15, Number 1, 2006

URI: https://id.erudit.org/iderudit/1072695ar

DOI: https://doi.org/10.7202/1072695ar

See table of contents

Publisher(s)

Canadian Philosophy of Education Society

ISSN

0838-4517 (print)

1916-0348 (digital)

Explore this journal

Cite this article

McCormick, M. \& Schleifer, M. (2006). Responsibility for Beliefs and Emotions. Paideusis, 15(1), 75-85. https://doi.org/10.7202/1072695ar
Article abstract

This paper maintains that the concept of responsibility must be extended to beliefs and emotions. It argues that beliefs and emotions have their crucial link through the element of judgment. Judgment refers to relationships in contexts of ambiguity and uncertainty; developing good judgment in children involves the question of similarities and differences in varying situations and contexts. Both beliefs and emotions are crucial to this process. Educators interested in helping develop better judgment must look at the relevant beliefs and emotions associated with the judgments we make. Just as children must be made aware of their responsibility for behaviour, so must they understand that they are responsible for their beliefs and emotions. (c) Miriam McCormick, Michael Schleifer, 2006

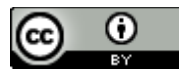

This document is protected by copyright law. Use of the services of Érudit (including reproduction) is subject to its terms and conditions, which can be viewed online.

https://apropos.erudit.org/en/users/policy-on-use/ 


\title{
Responsibility for Beliefs and Emotions
}

\author{
MIRIAM McCORMICK and MICHAEL SCHLEIFER \\ University of Richmond and Université du Québec à Montréal
}

\begin{abstract}
This paper maintains that the concept of responsibility must be extended to beliefs and emotions. It argues that beliefs and emotions have their crucial link through the element of judgment. Judgment refers to relationships in contexts of ambiguity and uncertainty; developing good judgment in children involves the question of similarities and differences in varying situations and contexts. Both beliefs and emotions are crucial to this process. Educators interested in helping develop better judgment must look at the relevant beliefs and emotions associated with the judgments we make. Just as children must be made aware of their responsibility for behaviour, so must they understand that they are responsible for their beliefs and emotions.
\end{abstract}

There exists a long tradition in regard to responsibility for actions and their consequences, including omissions to act. ${ }^{1}$ In moral education, an important part of what we want to instill in children is a sense of accountability, the importance of "taking responsibility" for what they do, and do not do. In this paper, we will argue that both the tradition and the educational message must be extended to beliefs and emotions.

Why are we speaking of beliefs and emotions together? Are not the former part of the cognitive ("epistemic") realm, connected to questions of knowledge, evidence, proof, and rationality, and the latter part of the affective realm, connected to feelings, and the world of passions, desires and the irrational? The answer to this question will be found in our detailed analysis of belief and emotion in the two sections below. What we will stress here is that beliefs and emotions have their crucial link through the element of judgment. Judgment refers to relationships in contexts of ambiguity and uncertainty; developing good judgment in children involves the question of similarities and differences in varying situations and contexts. ${ }^{2}$ Both beliefs and emotions are crucial to this process. As educators

\footnotetext{
${ }^{1}$ See, for example, John Martin Fischer and Mark Ravizzza Responsibility and Control, Cambridge University Press, Camrdige: 1998, M. Schleifer and C. Martiny Talking about values and feelings with young children Temeron Press, Calgary: 2005 ch.5, R.S. Peters. Authority, Responsibility and education, George Allen and Unwin, London: 1959, third edition 1973, Antony Flew, Crime or Disease Macmillan New York:1973. J. R. Lucas, The Freedom of the will, Clarendon Press, Oxford: 1970

2 See Schleifer, M. La formation du jugement, Éditions Logiques, Montreal : 1992 Particularly chapter 5, Judgment and Reasoning, , M Lipman, Thinking Children and Education. Kendall Publications, Iowa City: 1993 , p. 745. Lipman, M. (1992). "L'éducation au jugement", in La Formation du Jugement, ed. Michael Schleifer. pp. 99-123. (Available in English translation) Lipman, M. "Judgment and Person”, Montclair State University, New Jersey, unpublished paper, 1992. Hare, W. "Bertrand Russell on Critical Thinking”. Journal of Thought, 2001, pp. 7-16. Bruneau, S. Is there a political agenda behind critical thinking?. Paper presented at Canadian Society for the Study of Education, Brock University, 1996. Bailin, S., Case, R., Coombs, J.R. and Daniels, L.B. "Conceptualising Critical Thinking," Journal

(C) Copyright 2006. The authors, Miriam McCormick and Michael Schleifer, assign to Paideusis the right of first publication and educational and non-profit institutions a non-exclusive license to use this document for personal use and in courses of instruction provided that the article is used in full and this copyright statement is reproduced. Any other usage is probibited without the express permission of the authors.
} 
interested in helping develop better judgment, we will want to stress looking at the relevant beliefs and emotions associated with the judgments we make.

Just as children must be made aware of their responsibility for behaviour, so must they understand that they are responsible for their beliefs and emotions. In Section I, we outline our concept of responsibility. Section II presents our thesis about responsibility for beliefs, and Section III our point of view about responsibility for emotions.

\section{What is "Responsibility"?}

We want our children to be responsible. What do we mean by this? Responsibility is a complicated concept with moral, legal and psychological components ${ }^{3}$. For the purposes of this article, there is one main question to ask; namely, what is the value we want as parents and teachers to impart to our young children. To answer, we will sum up much of the philosophical and legal literature in the following way. Responsibility is: "Answering for what we do". We can see this in the roots of the word ("respondere," "to answer"). To account for our acts is what we have in mind: We want our children to understand that they are the authors of what they do, that when they do things that are bad, it may be appropriate to blame them (they are blameworthy), and when they do things that are good, they may deserve credit or praise (they are praiseworthy). We want them to understand that some things are done by them, sometimes by other people, and sometimes the causes are natural, or unknown.

At the very earliest ages of their lives, we identify our children by giving them a name, and then using this name when referring to their space, their possessions or their body (Mary's room, Mary's teddy-bear, Mary's nose), as well as to what action she did (Mary is walking, Mary is kissing, Mary is throwing a tantrum, Mary hurt her finger). We are reminding her that it is not daddy, or her brother who is walking, kissing, throwing a tantrum or whose finger is hurt. Personal identity and autonomy, two components of responsibility, make an appearance in very early childhood. The child, even before speaking, is very aware of his accomplishments. When a child first walks, for example, we (and the child) are proud of this developmental milestone The two year old, as every parent and early educator knows, insists on doing things for himself, and will persevere at a task for a very long time to get it done. It is often frustrating that the young child will refuse assistance for putting on his clothes. As good parents, we have learned to balance our wish to have our child have this important early autonomy, but also help him when it is needed, for his safety, or even because we are in a rush and can't afford the luxury of waiting for him to put on his own shoes. We, of course, have to exercise our judgment in balancing the competing values --- in this case, autonomy versus safety.

We want children to "take responsibility" for what they do. As we, and others, have argued elsewhere, ${ }^{4}$ taking responsibility does not entail being able to do otherwise. Whether or not one could

of Curriculum Studies, vol. 31, no 3, (19919), pp. 285-302. Giroux, A. 1990. "Enseigner à penser: passer de maître à mentor," Revue canadienne de l'éducation, vol. 15, no 3, pp. 229-244.

${ }^{3}$ See Peters, p.62, Flew, op.cit, Lucas, op.cit, , Schleifer and Martiny,op. cit. chapter 8 and David Owens. Reason Without Freedom: The Problem of Epistemic Normativity. Routledge, London: 2000. See also Strawson, P.F. Freedom and Resentment Studies in the Philosophy of Thought and Action London, Oxford University Press, London: 1968. Strawson mistakenly excludes children from his analysis of the "reactive attitudes" which are compatible with any kind of determinism. On this point, see M. Schleifer. "Psychological Explanations and Personal Relations" in A. Montefiore Philosophy and Personal Relations McGill-Queen's Press, Monttreal: 1973, pp. 170-191.

${ }^{4}$ See: note 1 above as well as Jean Piaget The Moral Judgment of the Child. Routledge and Kegan Paul, London: 1968. (Originally, Le jugement moral chez l'enfant. 1932). Shultz, T.-R., Schleifer, M., Jaggi, C., "Assigning vicarious responsibility." European Journal of Social Psychology, XVII, (1987), pp. 377-380. Shultz, T.-R., Wright, K., Schleifer, M., "Assignment of moral responsibility and punishment." Child Development, 57, (1986) pp. 177-184. Schleifer, M. Shultz, T.-R., Lefebvre-Pinard, M., ,Judgments of causality, responsibility, and punishment in cases of harm due to omission." British Journal of Developmental Psychology, 1(2), (1983) pp. 87-97. Shultz, T.-R., Schleifer, M., Altman, 
have done otherwise is irrelevant to taking responsibility, even if it remains crucial in determining other aspects of moral and legal responsibility. We can acknowledge that there are things we did (or omitted to do), which we could not have avoided doing (or failed to do). We may regret the consequences of some act, and want to apologize to people we may have hurt. We may, however, be practically certain that in the relevant circumstances, if offered the chance to go back again (perhaps by time-travel), we would still have acted in the same way. The act remains ours forever. Whether or not we are to be blamed (or praised) by others, and to what degree, is one matter. Our sense of being accountable to ourselves for our own acts is another.

The entire area of excuses, both in the law as well as in morality, is relevant to questions of blameworthiness, and circumstances may determine degrees of appropriate praise. Although all of this pertains to responsibility in the sense of accountability to others, none of it will determine one's own accountability. This is another way of stating our thesis: Taking responsibility is an independent matter of whether, or to what degree, we are morally or legally responsible. For children, "I couldn't help it" or "He made me do it" will have an impact on one issue (that of moral responsibility, including possible blame or punishment) but not on the other (acknowledging that it was their act, for which they must take responsibility).

Four further conceptual points: 1) We are speaking of responsibility as it occurs in its prepositional sense -- responsibility for something. There are uses of the concept which are subsidiary, as in "drink responsibly" (meaning, perhaps, "drink in moderation"), or simply " be responsible"

(which often means "be trustworthy, or "be mature"). 2) Responsibility refers not only to negative acts, as in crimes, bad behaviours, and other aspects for possible blame and punishment. We must also include good acts, good consequences, and the entire area of possible praise and reward. 3) Our concept of responsibility is not equivalent to blameworthiness, or praiseworthiness, but is to be defined independently of these. Of course, if a person is judged causally and morally responsible, it will make him a prime candidate for further questions of blame, praise, punishment, or reward, if these become relevant. 4) Finally, we are ignoring questions of collective and vicarious responsibility, where either groups of people, in the first case, or perhaps a parent in place of a child in the second, may be judged "responsible". For the purpose of this paper, we are restricting ourselves to the individual person who will be uniquely responsible for the act, omission to act, or the consequences of these. What we are arguing is that the same responsibility must be extended to both beliefs and emotions.

\section{Responsibility for Beliefs}

We express disapproval and approval for each others' beliefs, uttering such statements as, "How can you believe that?" or "What a ridiculous thing to believe!" It seems that when we make such admonishments, we think the person in question has formed the belief irresponsibly, and it seems we hold him responsible for forming this belief. This notion of responsibility is not simply one that is pointing out the causal genesis of the belief. Holding someone responsible for his beliefs is not like holding the wind responsible for knocking over the tent. That we praise and blame each other for the beliefs we hold seems to indicate, rather, that we view the beliefs one forms to be the consequence of one's agency.

We will investigate what we mean when we hold people responsible for beliefs, when we praise or blame them for beliefs they form or fail to form. In particular, we are interested in what kind of control is needed in belief maintenance for these "reactive attitudes" to be appropriate. When it comes to the issue of doxastic control, there are two main positions, both of which we reject. The first is

I., "Judgments of causation, responsibility, and punishment in cases of harm-doing." Canadian Journal of Behavioral Science/Revue canadienne des sciences du comportement, 13(3) (1981), pp. 238-253. Schleifer, M. "The responsibility of the psychopath. " Philosophy, 45(173), (1970) pp. 231-232 
doxastic voluntarism which claims that belief involves a decision, that is an act of the will. So, on this view, I can decide to believe in an afterlife if I think it will make my life more peaceful. The many problems with this position have been discussed extensively, perhaps most famously in Bernard Williams, "Deciding to Believe" 5 . But many who reject doxastic voluntarism conclude that we lack any kind of meaningful control in the doxastic realm. Those who take this line must explain what we are blaming these believers for, if not for failing to exercise control over their beliefs. We will argue that these responses fail because we do not end up blaming people for the particular beliefs they hold but for something only quite indirectly involved with this belief. We will then argue that if we want to hold people responsible for their beliefs, there needs to be a sense in which we have a kind of control over our beliefs which is not simply derivative. In formulating a view of the kind of control needed, we make use of some of the concepts involved in "guidance control." It means that beliefs are products of our agency -- something we have an active role in shaping and maintaining -- that there are ways in which "taking responsibility" for them means taking control. We are blamed when we lose this grasp, when we do not exercise our reflective and normative competence which helps us believe the way we ought to believe.

Given that we cannot be at will the way we can simply will ourselves to raise our arms (absent external force), what does this tell us about our being responsible for beliefs? One possibility is that it is mistaken to praise or blame one for the beliefs they hold or to see them as responsible. Just as I cannot help feeling wet when rain falls on me or hot when the sun is strong, my believing that it is raining or the sun is strong is not something that is "up to me"; it is a state I find myself in when the world impinges on me in certain ways. On such a view, belief is a passive phenomenon and it must be so, if it is to do its job. This is how David Owens (mistakenly) characterizes Hume's position : "In denying the existence of epistemic agency, doxastic responsibility and intellectual freedom, Hume means to reject the idea that belief is subject to reason. He allows that beliefs are governed by the sort of biological norms ${ }^{6}$ that apply to the process of breathing, or the workings of the human heart but no one thinks us responsible for non-compliance with such norms."

Others have not wanted to give up the notion of doxastic responsibility and so have argued that we can be held responsible for our beliefs even though we lack control over them. Owens argues that not only can we not believe at will, we do not have reflective control over our beliefs; a belief's rationality is not constrained by one's judgment of it the way an action is. A state is under reflective control, for Owens, "when it can be motivated by higher order judgments about the probative force of the reasons for it." 7 He cites McDowell, as well as Locke and Descartes, as theorists who think we do have such control over our beliefs, that our higher order judgments about what we ought to believe help to dictate what we do believe. Owens denies that we have this control largely because he thinks that such higher order judgments can fail to rationally motivate us. It is not by reflecting on reasons for believing that one comes to believe. We may reflect on evidence for or against $p$ in forming our belief of $p$ but we will not reflect on whether believing $p$ is rational, justified, desirable, or useful (even if we acknowledge such pragmatic considerations are part of what constitutes a belief's justification). We cannot, it seems, decide to favor one goal of believing over another, and believe it is raining or Jones is guilty as a result of this decision. "Purposiveness implies that a subject form beliefs in pursuance of a certain goal, that they control their beliefs by aiming at that goal"8 But believers lack this kind of control; our beliefs do not seem goal-oriented the way that our actions are. So, Owens argues, our blaming people is not a result of our taking them to have failed to exercise control, that they have failed to keep their beliefs in line with their more rational goals.

\footnotetext{
5 Williams, Bernard. "Deciding to Believe," Problems of Self., Cambridge University Press, Cambridge: 1973, pp. 136-151.

${ }^{6}$ Owens (2000), p. 2.

${ }^{7}$ Ibid, p. 4.

8 Owens, David. “Epistemic Akrasia," The Monist 85, (2002): pp. 381-397.
} 
If one takes it that responsibility entails control (a view Owens call the juridical theory of responsibility) and one agrees with Owens that we lack this control, one would have to deny that we are responsible (or blameworthy) for our beliefs. Given that Owens thinks we can (and ought) to be responsible for our beliefs, it must be the case that responsibility does not entail control. Rather, he argues, it is sufficient that a state be "responsive to reasons" in order for one to be held responsible for it, and beliefs are open to rational assessment in this way. ${ }^{9}$ If I hold a belief and am not responsive to the reasons that reveal the belief's irrationality, I can be held responsible (and blamed) for holding this belief. This is the case, for Owens, even if I could not have exercised better control, or even if I cannot alter my belief now. Rather, holding irrational beliefs is an epistemic vice, which, in turn, reveals a defect in my character. According to Owens, we are responsible for what determines our merit as people, even if we cannot control these determinants.

It seems odd to locate all responsibility for belief at the level of character for a number of reasons. First, given that the virtues we do or do not cultivate have so much to do with our upbringing, something clearly not up to us, can we really be responsible for our character? We don't want to dwell on this since it does seem we do, in many cases, take responsibility for the selves we are (personality etc.) even though we did not select who we are, since it is ourselves that are the sources of what we do. Our second problem with Owens is more serious; it seems to get the target of the blame wrong. On this view. when we blame you for having a particular belief, what we are actually doing is saying you are blameworthy for being in (or possessing) a state that is of a kind that is reason-responsive and you, because of a defect in your character, are failing to respond to reasons. But this is not blaming you for having THIS particular belief, say, your belief that your husband is having an affair, but rather for possessing a certain state that is of a kind which ought to be responsive to reasons.

Now consider someone who does possess the epistemic virtue of wisdom, who, as Owens puts it, "knows to whom credit is due, at what point to form a view, when to open his mind and when to close it" 10 and most of the time believes in such a way that manifests this virtue. If, one time, perhaps when overcome with jealousy, he forms a belief on insufficient evidence, would it really make sense for us to say "shame on you, you are lacking merit as a person as you clearly have not cultivated the virtue of wisdom"? Can we really even assess whether someone possesses a particular virtue based on one instance? It seems not, but we can still blame him in this one instance. We can blame him for having a belief he ought not to have; he ought not to have it because it is not in line with his higher order reflective judgment. We will argue that at least a part of our blame does indicate we think he has failed to exercise a kind of control.

Our third problem with Owens' account is that if we are really blaming people for their character traits, it would seem that we would blame someone less for the occasional lapse than we would someone who is always failing to respond to reasons, but it seems that, in fact, the opposite is true. If one has grown up in such a way as to be able to exercise epistemic virtues, but fails to keep one's beliefs in line with one's more reflective judgment, then one can be blamed for this lack of control. If someone has never, for example, learned to apportion his belief to the evidence, this person seems less blameworthy than one who knows that he ought to do so but who fails. The fact that we can even make the distinction between the lapses of the reflective person and the unreflective one seems to indicate that beliefs are more under our "reflective control" than Owens contends. For the wise person's beliefs will be more responsive to reasons than those of the unwise, and when the wise person's beliefs fail to be so, we blame him not for lacking virtue, but for being careless, for lacking self-control.

The bulk of the discussion of doxastic control focuses on the acquisition or formation of beliefs. Given that one cannot "believe at will," the main difficulty is to explain what is in the agent's control. There is a consensus that we have certain kinds of indirect control over what we believe. For example, in gathering and evaluating evidence that will be integral to my forming a belief, I engage in many intentional

${ }^{9}$ Owens (2000), pp. 115-129.

${ }^{10}$ Owens (2000), p. 125. 
activities. So the dispute concerns, rather, whether we have a form of control with respect to belief that is not derivative in this way. Gary Watson has recently argued that we do. ${ }^{11}$ Watson rejects the view that the kind of disanalogy Owens points to reveals that we lack control over our beliefs. Even if we are powerless to adopt beliefs just because we think they would serve our ends, it does not follow that beliefs are simply things "that happen to us, are effects upon us of the world." There does seem to be some room for agency and activity in the doxastic realm. Watson argues that this is the case because we can be held responsible for the judgments we make just as we can for the actions we perform. And, if this is so, there must be a sense in which what I believe is "up to me." Beliefs, it seems, are subject to my decision-making powers and my normative competence. One of the main conclusions Watson draws is that just because there is not an analogous doxastic will, this does not mean there is no room for doxastic agency. "The boundaries between the active and the passive are not marked by the will."12 Interestingly, Owens agrees with Watson on this point and spends much time arguing that practical judgment (rather than the will) is the instrument by which we control our agency. But as we have seen, Owens does not think a belief's rationality is constrained by one's judgment of it the way an action is. Higher order reflection can motivate our actions in a way that it cannot motivate our beliefs.

One of the reasons it may seem that we lack control over our beliefs is that so many of them seem unavoidable and irresistible. If it is impossible for me to avoid holding a particular belief, how can I be said to have any control over my holding it? For doesn't being in control entail that I could have done otherwise or that I could have chosen differently? There have been many theorists who have been concerned with formulating a concept of control (and responsibility) that does not entail that one could have done otherwise. For if causal determinism is true (or if God has created one and only one perfect world plan), there may be a sense in which we can never act other than we do, but it seems we would not want our notions of responsibility along with all the practices that go along with them to be rendered meaningless if it turned out that we did live in a deterministic universe. John Fischer calls the kind of control that does not entail alternative possibilities, "guidance control." To illustrate the kind of thing he has in mind, imagine that you are driving a car that is a "driver instruction" automobile with dual controls. As long as you are driving in a relatively safe manner, the instructor lets you control the car and so when you, at the correct time, turn to the right, it is you who is guiding the car to the right. But if you had shown signs of confusion and were about to mistakenly turn to the left, the instructor would have stepped in and steered it to the right. Thus you could have gone in no other direction but to the right. So, although you have guidance control over the car, you lack what Fischer calls "regulative control" -- the instructor has that.

In their recent book, ${ }^{13}$ Fischer and Ravizza provide detailed elaboration of this concept of guidance control and argue that it is sufficient for moral responsibility. We are not concerned with the details of their analysis or if the kind of control we have over beliefs directly maps on to what they have articulated, but much of their way of thinking about control seems to be getting at what we can do in the doxastic realm. It is being the author or guide of one's actions that they argue is the relevant sense of control in assessments of responsibility, not the principle of alternative possibilities. There are two main components to this notion of guidance control: Reason responsiveness and ownership. We have seen that Owens ties responsibility to reason responsiveness and thus argues that responsibility does not require control. But Fischer and Ravizza are adamant that responsibility requires control, just not the kind of "regulative control" which requires alternative possibilities. An agent exhibits guidance control of an action "insofar as the mechanism which actually issues in his action is his own, reasonsresponsive mechanism." Owens does not discuss the notion of ownership, but it is essential in trying to

\footnotetext{
11 Watson, Gary. "The Work of the Will," Weakness of Will and Practical Irrationality, Sarah Stroud and Christine Tappolet, eds. Clarendon Press Oxford: 2003, pp.172-200.

12 Ibid, p. 196.

${ }^{13}$ See note 1 above.
} 
understand how one can have guidance control over beliefs. If all that were required for responsibility is that the mechanism issuing in the action (or belief) were reason responsive, then even if one were directly manipulated - say, had scientists kidnapped you and implanted such a reason responsive mechanism -- you would still be responsible.

For the mechanism that actually issues in certain behavior to be one's own, one must take responsibility for it. Taking responsibility is understood historically. As one comes to view oneself as an agent, as having an effect on the world as a consequence of one's intentions, decisions etc., one comes to view oneself as a fair target for the reactive attitudes, such as punishment or praise. By viewing oneself as an appropriate target for the consequence of a particular mechanism (say, ordinary practical reasoning), one thereby takes responsibility for it and the behavior resulting from it. Once one takes responsibility for a particular mechanism then this ownership extends to future operations of the mechanism.

It seems evident that the actual mechanism issuing in a belief is reason responsive. So, say you believe, on inadequate evidence, that your brother stole some money from you. You discover your error (perhaps by finding the money or finding the real thief). You will then (under normal circumstances) revise your belief about your brother. But do we take responsibility for these mechanisms and for the resulting beliefs? Can we "own" them as a consequence of our agency the way we can our actions? We think we can see that this is possible if we think about our capacity to feel guilty about having certain beliefs. So consider again the belief about your brother. Even if you never acted on it in any way, you can still feel guilty having formed this belief at all. Owens thinks that such feelings of guilt would be appropriate and it would also be proper to blame you for having this belief. According to Owens, your guilt is not really about holding this belief and it certainly is not about a failure of control, but rather it is your feeling bad about not being a good person in general. But if you really viewed yourself as lacking control over this belief, would you feel the same kind of guilt for having it? Say you discovered that you had undergone some kind of psychic manipulation such that the mechanism responsible for issuing in beliefs about your brother was one which was controlled (via some remote control) by some evil scientist. You may still feel bad about having some beliefs, even a feeling of shame and a view about yourself that you were somehow defective. But part of your reasons for feeling guilty seem to have to do with this belief being a result of your agency. You have taken responsibility for the mechanism issuing in evidentially-based beliefs. When the mechanism is faulty, it is your fault and you can be said to have lost some control over this mechanism given that you are failing to guide your beliefs appropriately.

That some notion of control is in play when assigning blame to beliefs is reinforced if we consider when and why we mitigate such blame. Owens considers those theoriest who (he thinks, mistakenly) extend reflective control to the doxastic realm. According to this view, "we lose control when our mental life is not as we think it should be and we can't put it right." 14 His example is, if you keep having racist beliefs even when you recognize there are no grounds for it-when you think you should not. We think his characterization of loss of control is right. ${ }^{15}$ If you cannot make your higher order judgments effective, there is a sense in which your belief is no longer your own; you are divided and overpowered. But it seems in such a case we would blame you less if you really can not put it right; you are not as open to blame as someone who can put it right but who is failing to put in the care and effort required to do so.

\footnotetext{
14 Owens (2000), p. 11

15 A similar view of what a doxastic analogue to compelled action would be is discussed in Miriam McCormick, “Compelled Belief," American Philosophical Quarterly Vol. 42, no. 3, July 2005, pp. 157-169.
} 


\section{Responsibility for Emotions}

Emotions are a special sub-class of feelings which have, as stated above, a special closeness with beliefs via the concept of judgment. Other parts of the affective life, including motivation, impulses, desires, attitudes, dispositions, and mood will not be treated in this paper. We are prepared, however, to argue that people should take responsibility for much of the affective life. We specifically argue elsewhere that we should teach children to take responsibility for their moods. ${ }^{16}$ In this section, we will restrict ourselves to responsibility for emotions.

What are "emotions"? One way of seeing what emotions are, is to say what they are not. They are not just desires, impulses, or motives -- the things which may push us to action. They are different also from hunger and thirst, our two main appetites. Hunger is always about food, thirst always about drink. In contrast, emotions like love can have as object any number of people, or by extension, pets, books, music and so on. Nor can emotions be reduced to desires and passions, including sexual desire. Emotions are not pleasure and pain, although, of course, they may involve both these sensations. Attitudes, dispositions and moods are all causally and conceptually tied to emotions, although they have their own unique features. Having said what emotions are not, let us try a positive description. the best way of summing up a vast amount of philosophical and psychological literature of the last thirty years is to say: "Emotions are about something in the world." To be angry is to be angry "about" a peculiar sort of object, very much like "believing that" entails an object of belief. More recently, Martha Nussbaum has made her analysis of emotions partly a function of beliefs. She says, "It is, of course, a consequence of the view I have been developing that emotions, like other beliefs, can be true or false, and justified or unjustified, reasonable or unreasonable." 17

Nussbaum applies her general point to the question of changing one's beliefs and changing one's emotions, two processes which are inextricably linked. ${ }^{18}$ She cites Seneca's example of having been brought up to believe honor is very important, and then trying hard not to believe it. When he is seated at a table at a place which he considers insulting, he finds himself in the grip of old habits, still angry. The point of the example is that both the emotion and some associated false beliefs (we may have come to see them as false) are very difficult to shake off. Other examples mentioned by Nussbaum are the fear a person may have of dogs as a child, or some racist beliefs with accompanying attitudes transmitted by parents. The emotions and beliefs are, as with Seneca, hard to give up, sometimes throughout adult life.

If we ask ourselves what do we naturally call emotions, we would give quite a long list which would include fear, anger, joy, sorrow, grief, jealousy, pity, shame, guilt, pride, hope, wonder, love, hate, and the like. What sort of criteria underlies this selection? The connection is that all these emotions are forms of cognition; they are sometimes called "appraisals." All emotions involve seeing situations under certain aspects which are agreeable or disagreeable and beneficial or harmful in a variety of dimensions. To feel fear $i s$, for instance, to see a situation as dangerous. To feel pride is to see with pleasure something as mine, or as something that I have had a hand in bringing about. Nussbaum argues that emotions should be understood as "geological upheavals of thought." "Emotions," she says, "are judgments in which people acknowledge the great importance, for their own flourishing, of things that they do not fully control -- and acknowledge thereby, their neediness before the world and its event."19 Nussbaum credits the Stoics for the essence of this view that emotions are judgments.

For the purpose of the present paper, we accept the cognitivist analysis of emotion which is sketched above. The essential point to our view, which follows Aristotle and Nussbaum, is that

\footnotetext{
16 Schleifer, Michael and McCormick, Miriam "Are we responsible for our emotions and moods?" Thinking: The Journal of Philosophy for Children, Volume 18, no. 2, Fall 2005.

${ }_{17}$ Martha Nussbaum Upheavals of Thought Cambridge University Press, Cambridge: 2001, p. 46 our emphasis.

${ }^{18}$ Ibid, p. 35. See also McCormick.

${ }^{19}$ Nussbaum, p. 33.
} 
emotions are a form of judgment. It is only fair, however, to mention that there is an opposing group of philosophers who insist that emotions should be primarily defined not in terms of cognition, but rather in terms of physiological changes and action tendencies. ${ }^{20}$

There is no consensus about whether emotions are uniquely human, or whether other animals have emotions as well. The Stoics, as Nussbaum points out, were convinced that no animal could have any emotion. Nussbaum herself, along with a philosopher/dog-owner called George Pitcher ${ }^{21}$ argue (we think persuasively) that some animals display grief, anger and love. There seems also to be a modern consensus among philosophers and psychologists about the emotion of fear. Every creature seems to have fear built into whatever brain it possesses. It is no doubt for this reason that most of the recent, exciting research on the physiology of emotion has concentrated on the emotion of fear. ${ }^{22}$ In our view, disgust (often listed along with surprise, anger, fear, sadness and joy as basic emotions with universal facial expressions) is probably uniquely human. We certainly take emotions like pride, shame, and hope to be uniquely human. This is because there are elements of thought involved of a kind of whichonly humans are capable. Among other concepts necessary to these emotions are a consciousness of time, of past and future, something of which only people seem to be capable. Pride is about things we have judged to have done in the past which we consider due to certain effort, and as an accomplishment. Shame relates to an ideal of ourselves which we have, and feel less than perfect about. Hope involves expectations about the future, along with certain associated fears.

To illustrate our point of view concerning responsibility for emotions, we will consider two examples. The first concerns gratitude, the second apology and regret. Although some might want to contend that animals have these emotions in some sense, we are using them in a way which is uniquely human. Gratitude and regret will be linked to the past, to a history, and thus like pride, shame and hope will need the ability to conceptualize time.

Fischer and Ravizza discuss an example about gratitude. They contend that their analysis of moral responsibility for acts, omissions, and consequences, should in theory be extended to the realm of emotions. They do not provide the extension themselves, but challenge others to provide the demonstration. They consider one attempt to do so by Robert Adams in an article entitled "Involuntary Sins." In brief, Adams argues, against Fischer and Ravizza, that we are morally responsible for emotions, independently of questions of voluntariness, or, for that matter, any form of control. The important example concerns gratitude:

Suppose you have just realized that you are ungrateful to someone who has done a lot for youperhaps at a great cost to herself. Far from responding to her sacrifices with love and gratitude, you have made light of them in your own mind; and if the truth be told, you actually resent them, because you hate to be dependent on others, or indebted to them. Surely this attitude is blameworthy. ${ }^{23}$

We want to assert, with Adams, that we are morally responsible for our emotion of gratitude (or, as in this case, its absence). There are things that we can do to improve our state of mind; we can acknowledge the lack of relevant emotion, and make some effort towards feeling it appropriately. It is not a question of faking the emotion, nor simply of working on behaviour (for example, expressing gratitude). It is directly concerned with the emotion itself. In the sense of responsibility outlined above,

\footnotetext{
20 Among philosophers Paul Griffiths is a representative of this view. See his, What Emotions Really Are, University of Chicago Press, Chicago: 1977. Another is Jenefer Robinson, Deeper Than Reason, Oxford University Press, Oxfod: 2005. Among psychologists, the leading representative would be Nico Fridja, The Emotions, Cambridge University Press Cambridge: 1986.

${ }^{21}$ Pitcher, G., The Dogs Who Came to Stay, Dutton, New York: 1995.

22 See Ledoux, Paul, The Emotional Brain: The Mysterious Underpinnings of Emotional Life, Simon and Schuster, New York: 1993.

${ }^{23}$ Adams, Robert. “Involuntary Sins” Philosophical Review (1985), pp. 3-31
} 
we are responsible for our emotion of gratitude, just as we would be responsible for an act, an omission, or a consequence. An important aspect of moral education is to make children aware of when and why gratitude is fitting, and to discuss why one does not have the emotion where it may be appropriate. With Adams, and against Fischer and Ravissa on this point, we are extending the full concept of responsibility to the realm of emotions.

Our second example comes from the area of apology and regret. We have argued elsewhere ${ }^{24}$, as have others ${ }^{25}$, that moral educators must stress genuine apologies, which can lead, in turn, to forgiveness by the person who has been wronged. We may, however, reflect about something we have done, and not bring ourselves to feel the regret which could lead to a genuine apology. We may, furthermore, think that it would be more appropriate if we really did feel regret about what we said, did, or omitted to say or do. We can resolve to take steps to work on feeling the emotion of regret, and feeling the need to apologize instead of simply mouthing the words, or faking it.

In both the gratitude and regret examples, we feel that an important task for moral education (teachers, parents, child-care workers) is to impart the need to take responsibility for one's emotion. In a way appropriate to the age-level of the child, one finds a way to discuss the concept, talking about "thank you" in the first example, and "sorry" in the second. One can, and should, begin this discussion at very early ages, certainly during the preschool years (two to five). Partly because of Piaget and others, we have seriously underestimated the competence of young children, and their ability to comprehend these matters. Research of the last twenty years has shown that, contrary to Piaget, by the age of five, the child is very sophisticated in his understanding of questions of responsibility. ${ }^{26}$

Whether or not, to what degree, and in what way, emotions can be controlled is an important issue, not directly discussed in the present paper. Recent research on the "emotional brain" by Joseph Ledoux, and popularized by Daniel Goleman, ${ }^{27}$ has shown that certain basic emotions like fear and anger are much too rapid to be controlled by any person. The amygdala reacts in 12 milliseconds, independently of any cortical connections. On the other hand, there are techniques which can be used to control duration, intensity, and some manifestations of fear and anger, as Goleman and others have shown. With fear and anger, there is inevitably some part of the process which cannot be controlled by most people (mainly bodily and brain), although there are other things one can do about anticipating circumstances, and regulating expressions and manifestations, in verbal and non-verbal behaviour.

Gratitude and regret are more complicated emotions, and talking about control may be inappropriate and misleading. What should be noted is that in all four cases, (fear, anger, gratitude and regret), we can, and should, talk about responsibility in a double sense. Firstly, it is being one's unique act, and open to possible blame and praise that makes attributions of responsibility appropriate. Secondly, we can take responsibility for the emotion in the sense that we can reflect about it, and make a decision or adopt a policy to do something about it. We might say that it is a matter of "taking control" of the emotion, whether or not the first occurrence of the emotion was open to control or regulation.

Questions about control and regulation of emotion are complicated and important matters, which should certainly be talked about with children. In this paper, our aim has been to stress the importance of discussing emotions, understanding them better, and taking responsibility for them in the present, independently of whether or not, and to what degree, they could have been controlled or regulated in the past.

${ }^{24}$ Schleifer, M., "To Speak or to Keep Silent." Annual meeting of the British Society for Philosophy of Education Oxford, April 2005.

${ }^{25}$ White, Patricia "What should we teach children about forgiveness?" Journal of Philosophy of Education, vol. 36(10), 2002, 57-67.

${ }^{26}$ Shultz, Wright and Schleifer. "Assignment of Moral Responsibility and Punishment" Child Development (1986). See also Bryant, P.E. "Piaget, Teachers and Psychologists" Oxford Review of Education 10, no.3 (1948), pp. 25l-259.

${ }^{27}$ Goleman, Daniel, Emotional Intelligence, Bantam Books, New York: 1995, p. 23., Ledoux,op.cit note 23 above. 


\section{About the Authors}

Miriam McCormick is an Associate Professor of Philosophy at the University of Richmond. She came to Richmond in 2000 after receiving her B.A. and Ph.D from McGill University and teaching at Grinnell College. Her main areas of interest are in early modern philosophy and epistemology. Her articles have appeared in American Philosophical Quarterly, Hume Studies, History of Philosophy Quarterly and the Canadian Journal of Philosophy.

Michael Schleifer, professor of Education at the Universite de Quebec a Montreal, has published numerous articles in philosophy, psychology and education journals. He is currently doing research on the development and education of emotions. His book entitled, Talking About Feelings and Values With Children" was published in 2005 by Temeron Press. 